\title{
Warifteine, a bisbenzylisoquinoline alkaloid, induces relaxation by activating potassium channels in vascular myocytes
}

\author{
Ápio CL Assis, ${ }^{* \dagger}$ Islania GA Araújo, ${ }^{* \dagger}$ Renata PC Lima,* Mônica M Almeida,* Alexsandro F Marinho,* \\ José M Barbosa-Filho, ${ }^{*}$ Jader S Cruz, ${ }^{\ddagger}$ Darizy F Silva ${ }^{\S}$ and Isac A Medeiros* \\ *Laboratory of Pharmaceutical Technology, Federal University of Paraíba, João Pessoa, ${ }^{\dagger}$ Department of Physiology and \\ Pathology, Federal University of Paraíba, João Pessoa, ${ }^{\star}$ Institute of Biological Sciences, Federal University of Minas \\ Gerais, Belo Horizonte, and ${ }^{\S}$ Department of Bioregulation, Federal University of Bahia, Salvador, Brazil
}

\section{SUMMARY}

1. The present study used functional and electrophysiological approaches to investigate the mechanisms by which warifteine, a bisbenzylisoquinoline alkaloid isolated from Cissampelos sympodialis Eichl., causes vasorelaxation of the rat thoracic aorta.

2. Warifteine $(1 \mathrm{pmol} / \mathrm{L}-10 \mu \mathrm{mol} / \mathrm{L})$ induced concentration-dependent relaxation $\left(\mathrm{pD}_{2}=9.40 \pm 0.06 ; n=5\right)$ of endothelium-intact aortic rings precontracted with noradrenaline $(10-100 \mu \mathrm{mol} / \mathrm{L})$. The relaxation effects were not attenuated by removal of the endothelium. Warifteine also induced the relaxation of prostaglandin $\mathbf{F}_{2 \alpha}$ (1-10 mmol/L)-precontracted rings $\quad\left(\mathrm{pD}_{2}=9.2 \pm 0.2\right.$; $n=8)$. In contrast, the relaxant activity of warifteine was nearly abolished in high $\mathrm{K}^{+}(80 \mathrm{mmol} / \mathrm{L})$-precontracted aortic rings. In preparations incubated with $20 \mathrm{mmol} / \mathrm{L}$ $\mathrm{KCl}$ or with the $\mathrm{K}^{+}$channel blockers tetraethylammonium (1, 3 and $5 \mathrm{mmol} / \mathrm{L})$, iberiotoxin $(20 \mathrm{nmol} / \mathrm{L})$, 4-aminopyridine $(1 \mathrm{mmol} / \mathrm{L})$ or glibenclamide $(10 \mu \mathrm{mol} / \mathrm{L})$, the vasorelaxant activity of warifteine was markedly reduced. However, $\mathrm{BaCl}_{2}(1 \mathrm{mmol} / \mathrm{L})$ had no effect on the relaxant effects of warifteine.

3. In vascular myocytes, warifteine $(100 \mathrm{nmol} / \mathrm{L})$ significantly increased whole-cell $\mathrm{K}^{+}$currents (at $70 \mathrm{mV}$ ). Under nominally $\mathrm{Ca}^{2+}$-free conditions, warifteine did not reduce extracellular $\mathrm{Ca}^{2+}$-induced contractions in rings precontracted with high $\mathrm{K}^{+}$or noradrenaline $(100 \mu \mathrm{mol} / \mathrm{L})$.

4. Together, the results of the present study indicate that warifteine induces potent concentration-dependent relaxation in the rat aorta via an endothelium-independent mechanism that involves the activation of $\mathrm{K}^{+}$channels.

Key words: bisbenzylisoquinoline alkaloid, potassium channels, rat aorta, vascular smooth muscle cells, vasodilatation, warifteine.

Correspondence: Professor Darizy F Silva, Departamento de Biorregulação, Universidade Federal da Bahia (UFBA), Vale do Canela, Salvador, BA 40110-902, Brazil. Email: darizy@gmail.com

Received 22 July 2012; revision 17 October 2012; accepted 21 October 2012.

(C) 2012 The Authors

Clinical and Experimental Pharmacology and Physiology

(C) 2012 Wiley Publishing Asia Pty Ltd

\section{INTRODUCTION}

Hypertension is a global public health concern that is universally accepted as an important prognostic factor for cardiovascular diseases and premature mortality. Therefore, the prevention and treatment of hypertension remain a priority for the medical community. ${ }^{1}$

Substances derived from natural products are an important source of new medicines. Alkaloids constitute the largest class of botanical secondary metabolites, exhibiting therapeutic effects, such as antirheumatic, ${ }^{2}$ antihyperglycaemic, ${ }^{3}$ antiviral ${ }^{4}$ and antiinflammatory actions. ${ }^{4,5}$ From this group of naturally occurring organic compounds, the bisbenzylisoquinoline alkaloids (e.g. cycleanine, tetrandine and berbamine) exhibit diverse biological activities, such as suppression of hepatic injury and the production of tumour necrosis factor in Bacille Calmette-Guerin plus lipopolysaccharide-treated mice. ${ }^{6,7}$ In addition to its antihypertensive effect on spontaneously hypertensive rats, renal hypertensive rats and deoxycorticosterone acetate-salt hypertensive rats, ${ }^{8}$ tetrandine has been shown to decrease systolic and diastolic arterial pressure in humans. ${ }^{9}$ Dauricine and daurisoline have been shown to have anti-arrhythmic actions, ${ }^{10}$ providing further evidence of the beneficial cardiovascular effects of bisbenzylisoquinoline alkaloids. Therefore, further studies into this chemical structure may result in new treatments for cardiovascular problems, such as arrhythmia and hypertension.

Cissampelos sympodialis Eichl. (Menispermaceae), a species found in north-eastern and south-eastern Brazil, has been used in folk medicine for the treatment of rheumatism, colds, asthma and other conditions. ${ }^{11}$ Phytochemical analyses of the roots of this plant revealed the presence of a group of alkaloids, namely warifteine, methylwarifteine, roraimine and milonine. Warifteine $\left(\mathrm{C}_{36} \mathrm{H}_{36} \mathrm{~N}_{2} \mathrm{O}_{6}\right.$; molecular weight 592.7; Fig. 1), a bisbenzylisoquinoline alkaloid, ${ }^{12}$ is the predominant component isolated from the ethanolic extract of $C$. sympodialis root bark. Several studies have shown promising pharmacological effects of $C$. sympodialis and warifteine on biological systems, including immunomodulation, ${ }^{13}$ antidepressant effects $^{14}$ and inhibition of eosinophil recruitment. ${ }^{11}$ However, few reports have investigated the effects of warifteine on vasomotor tone, despite the known antiarrhythmic and antihypertensive properties of compounds from the same chemical class as warifteine. Previous studies have demonstrated that warifteine induces concentration-dependent relaxation of the rabbit aorta. ${ }^{12}$ This relaxation was shown to be 


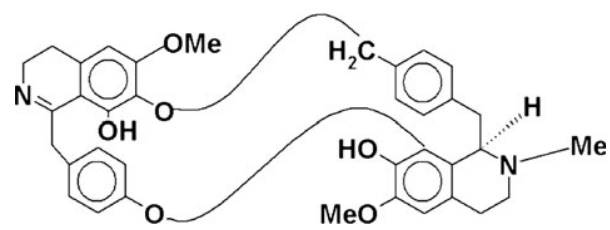

Fig. 1 Chemical structure of warifteine.

due to inhibition of voltage-dependent $\mathrm{Ca}^{2+}$ channels (VDCC), receptor-operated $\mathrm{Ca}^{2+}$ channels and $\mathrm{Ca}^{2+}$ liberation from noradrenaline-sensitive intracellular stores in the rabbit aorta. ${ }^{12}$ However, the mechanism underlying warifteine-induced relaxation of the vascular smooth muscle remains unclear. In the present study, the vasorelaxant effects of warifteine were examined in the rat aorta using combined functional and electrophysiological approaches.

\section{METHODS}

\section{Animals}

This study was performed in accordance with the Guide for the Care and Use of Laboratory Animals as adopted by the US National Institutes of Health (http://oacu.od.nih.gov/regs/guide/ guide_2011.pdf, accessed November 2011) and was approved by the Animal Care and Use Committees of the Federal University of Paraíba and the Federal University of Minas Gerais. Male Wistar rats $(250-300 \mathrm{~g})$ were used for all experiments. Rats were housed under temperature-controlled $\left(21 \pm 1^{\circ} \mathrm{C}\right)$ conditions and a $12 \mathrm{~h}$ light-dark cycle (lights on 0600-1800 h). In addition, rats had free access to food (PURINA-Brazil, Canoas, Brazil) and tap water.

\section{Preparation of thoracic aortic rings}

Rats were killed in a $\mathrm{CO}_{2}$ gas chamber and the thoracic aorta was isolated and placed in Krebs' solution (composition (in mmol/L): $\mathrm{NaCl} 118 ; \mathrm{KCl} 4.7 ; \mathrm{NaHCO}_{3} 25 ; \mathrm{CaCl}_{2}$ 2.5; glucose 11.1; $\mathrm{KH}_{2} \mathrm{PO}_{4}$ 1.2; $\mathrm{MgSO}_{4}$ 1.2). Fat and connective tissues were removed carefully and the aorta was cut into $2-4 \mathrm{~mm}$ rings. The endothelium was removed mechanically when necessary by gently rubbing the intimal surface with a metal rod. The aortic rings were suspended horizontally between two stainless steel wires in organ baths containing Krebs' solution, maintained at $37^{\circ} \mathrm{C}$ and gassed with $95 \% \quad \mathrm{O}_{2}$ and $5 \% \mathrm{CO}_{2}$. Isometric tension was recorded with a force-displacement transducer (FORT-10; World Precision Instruments (WPI), Sarasota, FL, USA) coupled to an amplifier-recorder (Transbridge-4; WPI). Rings were stabilized under a resting tension of $2 \mathrm{~g}$ for $1 \mathrm{~h}$. The presence of functional endothelium was assessed by the ability of acetylcholine $(1 \mu \mathrm{mol} / \mathrm{L})$ to induce relaxation of at least $80 \%$ in vessels precontracted with phenylephrine $(1 \mu \mathrm{mol} / \mathrm{L})$. The absence of acetylcholine-mediated relaxation in vessel segments was indicative of a functionally denuded endothelium.

\section{Vasorelaxant effects of warifteine in precontracted aortic rings}

The first series of experiments examined the effects of warifteine on sustained contractions induced by noradrenaline $(10-100 \mu \mathrm{mol} / \mathrm{L})$.
After the equilibration period, aortic rings, with or without functional endothelium, were precontracted with the agonist. Once a plateau had been attained, cumulative concentration-dependent relaxation curves were constructed to warifteine ( $1 \mathrm{pmol} / \mathrm{L}-$ $10 \mu \mathrm{mol} / \mathrm{L})$. Experiments were also performed in endotheliumdenuded mesenteric rings precontracted with prostaglandin (PG) $\mathrm{F}_{2 \alpha}(1-10 \mathrm{mmol} / \mathrm{L})$ or high $\mathrm{K}^{+}(80 \mathrm{mmol} / \mathrm{L})$ to further explore the mechanisms underlying warifteine-induced vasorelaxation. Control experiments conducted in the absence of warifteine were performed to monitor the stability of the noradrenaline-, $\mathrm{PGF}_{2 \alpha^{-}}$or high $\mathrm{K}^{+}$-induced contractions. In each experiment, a concentrationresponse curve was constructed to the contractile agent to enable rings to be contracted to the same degree. High- $\mathrm{K}^{+} \mathrm{Krebs}$ ' solution were prepared by replacing $\mathrm{NaCl}$ with an equivalent amount of $\mathrm{KCl}$ to maintain osmolarity.

\section{Role of $\mathrm{K}^{+}$channels in warifteine-induced vasorelaxation}

The vasorelaxant effects of warifteine were examined in endothelium-denuded rat aortic rings exposed to Krebs' solution containing increasing concentrations of $\mathrm{K}^{+}$(from 4.7 to $20 \mathrm{mmol} / \mathrm{L}$ ) to investigate whether the warifteine-induced relaxation was due to potassium channel activation. Increasing external $\mathrm{K}^{+}$concentrations decreases $\mathrm{K}^{+}$efflux and prevents relaxation mediated by the opening of $\mathrm{K}^{+}$channels. To investigate which $\mathrm{K}^{+}$channels were involved in the vasorelaxant responses to warifteine, endotheliumdenuded aortic rings were pretreated for $30 \mathrm{~min}$ with tetraethylammonium (TEA; 1,3 and $5 \mathrm{mmol} / \mathrm{L})$, iberiotoxin $(20 \mathrm{nmol} / \mathrm{L})$, 4-aminopyridine $(1 \mathrm{mmol} / \mathrm{L})$, barium $(1 \mathrm{mmol} / \mathrm{L})$ or glibenclamide $(10 \mu \mathrm{mmol} / \mathrm{L})$ prior to being precontracted with noradrenaline $(10-100 \mu \mathrm{mol} / \mathrm{L})$. Shortly after its addition, TEA produced a slight change in arterial basal tone (from $1.70 \pm 0.12$ to $2.41 \pm 0.22 \mathrm{~g}$ ). However, in all our experiments, only arterial rings that demonstrated the same magnitude of contraction were used. Cumulative concentration-response curves were then constructed and compared with those obtained in vessels that had not been pretreated with the $\mathrm{K}^{+}$channel blockers.

\section{Effects of warifteine on $\mathrm{Ca}^{2+}$-induced contractions}

To further examine the effects of warifteine on $\mathrm{Ca}^{2+}$ influx through the plasma membrane, two sets of experiments were performed in endothelium-denuded aortic rings. In the first set of experiments, extracellular $\mathrm{Ca}^{2+}$ was removed by washing the vessels with $\mathrm{Ca}^{2+}$ free Krebs' solution, which had the same composition as Krebs' solution but without $\mathrm{CaCl}_{2}$ and with the addition of $1 \mathrm{mmol} / \mathrm{L}$ EGTA, followed by a series of additions of noradrenaline $(100 \mu \mathrm{mol} / \mathrm{L})$ to deplete intracellular $\mathrm{Ca}^{2+}$ stores. After the depletion of intracellular $\mathrm{Ca}^{2+}$ stores, as confirmed by the loss of contractile responses to noradrenaline, the rings were maintained in $\mathrm{Ca}^{2+}$-free Krebs' solution. Following a 10 min equilibration period, vascular contractions were initiated by the addition of $\mathrm{CaCl}_{2}$ ( $2 \mathrm{mmol} / \mathrm{L}$ ) to the organ baths, either the absence (control) or the presence of warifteine (10 $\mu \mathrm{mol} / \mathrm{L}, 15 \mathrm{~min})$.

In the second set of experiments, $\mathrm{CaCl}_{2}$-induced contractions were investigated in rings stabilized in high- $\mathrm{K}^{+}(60 \mathrm{mmol} / \mathrm{L})$, nominally $\mathrm{Ca}^{2+}$-free, Krebs' solution (Krebs' solution without $\mathrm{CaCl}_{2}$ and no EGTA added). Contractions were induced by the 
cumulative addition of $\mathrm{CaCl}_{2}(1 \mu \mathrm{mol} / \mathrm{L}-30 \mathrm{mmol} / \mathrm{L})$ in the absence (control) or presence of $10 \mu \mathrm{mol} / \mathrm{L}$ warifteine.

\section{Isolation of vascular myocytes}

Vascular myocytes were isolated enzymatically from rat aorta using a procedure similar to that reported previously. ${ }^{15}$ Briefly, small pieces of endothelium-free rat aorta were placed in a physiological solution (PS; composition (in mmol/L): $\mathrm{NaCl} 137 ; \mathrm{KCl}$ 5.6; $\mathrm{MgCl}_{2} 1 ; \mathrm{CaCl}_{2}$ 2.6; $\mathrm{NaHCO}_{3}$ 4.17; $\mathrm{NaH}_{2} \mathrm{PO}_{4} \quad 0.44 ;$ $\mathrm{Na}_{2} \mathrm{HPO}_{4}$ 0.42; glucose 5; HEPES 10) containing $0.7 \mathrm{mg} / \mathrm{mL}$ papain (Sigma-Aldrich, St Louis, MO, USA), $1 \mathrm{mg} / \mathrm{mL}$ albumin (Sigma-Aldrich) and $1 \mathrm{mg} / \mathrm{mL}$ dithiothreitol (Sigma-Aldrich), and were incubated at $37^{\circ} \mathrm{C}$ for $30 \mathrm{~min}$. After $30 \mathrm{~min}$ in the enzymatic solution, the pieces of tissue were removed, washed in enzyme-free physiological solution and exposed to a low- $\mathrm{Ca}^{2+}$ PS (the same composition as the PS, except with $0.05 \mathrm{mmol} / \mathrm{L}$ $\mathrm{CaCl}_{2}$ and $3.55 \mathrm{mmol} / \mathrm{L} \mathrm{MgCl}_{2}$ ) containing $1 \mathrm{mg} / \mathrm{mL}$ collagenase, $0.9 \mathrm{mg} / \mathrm{mL}$ hyaluronidase (Sigma, St Louis, MO, USA) and $1 \mathrm{mg} / \mathrm{mL}$ albumin (Sigma). Single cells were obtained by gentle titration with a Pasteur pipette. Aliquots of single cell suspensions were then placed in experimental chambers for electrophysiological recordings. All experiments were performed on the day of isolation.

\section{Electrophysiological recordings}

Potassium currents were recorded using the whole-cell, patchclamp configuration ${ }^{16}$ at room temperature $\left(23-25^{\circ} \mathrm{C}\right)$. Borosilicate glass pipettes were pulled from glass capillaries (Perfecta, São Paulo, Brazil) using a micropipette puller (PP-830; Narishige, Tokyo, Japan). Pipettes were filled with $\mathrm{K}^{+}$-based pipette solution (composition (in mmol/L): $\mathrm{KCl} \mathrm{130;} \mathrm{NaCl} \mathrm{5}$; EGTA 5; HEPES 5, $\mathrm{pH}$ adjusted to 7.4 with $\mathrm{KOH}$ ) and carried resistances between 2 and $4 \mathrm{M} \Omega$. An $\mathrm{Ag}-\mathrm{AgCl}$ wire was used as the reference electrode. The composition of the external solution was (in $\mathrm{mmol} / \mathrm{L}$ ): $\mathrm{NaCl} 137 ; \mathrm{KCl}$ 5.6; $\mathrm{MgCl}_{2} 1 ; \mathrm{CaCl}_{2}$ 2.6; $\mathrm{NaHCO}_{3} 4.17$; $\mathrm{NaH}_{2} \mathrm{PO}_{4} \quad 0.44 ; \mathrm{Na}_{2} \mathrm{HPO}_{4} \quad 0.42 ;$ glucose 5; HEPES $10(\mathrm{pH}$ adjusted to 7.4 with $\mathrm{NaOH}$ ). This solution was gravity delivered, controlled by solenoid valves. Data were acquired using EPC-9 patch clamp amplifiers and 'Pulse' acquisition software (HEKA Electronik, Lambrecht, Germany), low-pass filtered at $3 \mathrm{kHz}$ and sampled at $10 \mathrm{kHz}$. Cancellation of the capacity transients and leak subtraction were performed using a programmed $\mathrm{P} / 4$ protocol. ${ }^{17}$ Cells with a visible changes in leakage currents throughout the study were discarded. The cell membrane capacitance was $11.50 \pm 0.14 \mathrm{pF}(n=24)$. Families of the macroscopic $\mathrm{K}^{+}$currents were generated stepwise by $10 \mathrm{mV}$ depolarizing pulses (pulse duration $200 \mathrm{msec}$; holding potential $-40 \mathrm{mV}$ ) from -50 to $-70 \mathrm{mV}$. Current amplitude was recorded before (control) and during (treatment) the application of a drug.

\section{Chemicals}

Noradrenaline, $\mathrm{PGF}_{2 \alpha}$, phenylephrine, acetylcholine, EGTA, albumin, 4-aminopyridine, glibenclamide, hyaluronidase Type II, papain, DL-dithiothreitol, TEA, cremophor and dimethyl sulphoxide were purchased from Sigma-Aldrich. Collagenase Type II (CLS2) was purchased from Worthington Corporation (Freehold,
NJ, USA). Warifteine was solubilized in a mixture of $50 \mu \mathrm{L}$ cremophor $1000 \mu \mathrm{L}$ water and diluted to the desired concentration just before use. The final concentration of cremophor in the tissue bath never exceeded $0.01 \%$. At that concentration, L-cremophor did not have any measurable effects in our experiments (data not shown).

\section{Curve fitting and statistics}

Data are presented as the mean \pm SEM of $n$ rings prepared from different rats. Concentration-response curves to warifteine were based on the percentage relaxation of agonist-induced contractions. A value of $100 \%$ relaxation was assigned when the precontracted rings returned to baseline tension. Curves were fitted using a variable slope sigmoid fitting routine in Prism4 (GraphPad, San Diego, CA, USA). The $\mathrm{pEC}_{50}$ (negative log of the concentration required to produce $50 \%$ relaxation) and $\mathrm{E}_{\max }$ (maximum percentage relaxation) values were calculated from the fitted sigmoidal curves. Statistical analyses were performed to compare $\mathrm{E}_{\max }$ and $\mathrm{pEC}_{50}$ values between groups of independent observations. Unpaired or paired Student's $t$-test or oneway ANOVA were used to compare two, three or more groups, respectively, followed by Bonferroni's multiple comparisons post-test with correction to avoid the risk of Type 1 and Type 2 errors. These corrections were performed to gain better protection against $\alpha$-level inflation due to multiple tests of significance. Thus, for our data, the overall $\alpha$-level (0.05) was divided among the number of tests of significance tested. The new $\alpha$-level used in the equation was $\alpha=$ (desired for entire study/ no. significance tests done). Two-sided $P<0.05$ was considered significant.

Electrophysiological data were analysed using the 'Pulse-Fit' analysis program (HEKA Elektronik) and SigmaPlot (SPSS, Chicago, IL, USA). Current-voltage relationships were calculated on the basis of the peak values (leakage corrected) from the original currents.

\section{RESULTS}

\section{Relaxant effects of warifteine in rat thoracic aorta}

Figure 2a shows warifteine-mediated relaxation responses in rat aortic rings. Cumulative addition of warifteine $(1 \mathrm{pmol} / \mathrm{L}-$ $10 \mu \mathrm{mol} / \mathrm{L}$ ) resulted in concentration-dependent vasorelaxation of endothelium-intact rings precontracted with noradrenaline (10$\left.100 \mu \mathrm{mol} / \mathrm{L} ; \mathrm{pD}_{2}=9.40 \pm 0.06 ; \quad \mathrm{E}_{\max }=97.3 \pm 1.2 \% ; n=5\right)$. Removal of the endothelium had no significant effect on the $\mathrm{pD}_{2}$ or $\mathrm{E}_{\max }$ of warifteine-induced relaxations $\left(\mathrm{pD}_{2}=9.20 \pm 0.10\right.$; $\mathrm{E}_{\max }=88.41 \pm 3.83 \% ; n=5 ; P>0.05$ compared with endothelium-intact rings, unpaired Student's $t$-test; Fig. 2b; Table 1). However, the vasorelaxant effects of two concentrations of warifteine $\left(10^{-9}\right.$ and $\left.10^{-8} \mathrm{~mol} / \mathrm{L}\right)$ differed significantly between endothelium-intact and -denuded rings $(P<0.05$ and $P<0.01$, respectively, unpaired Student's $t$-test). These results suggest that warifteine predominantly acts on arterial smooth muscle. Because there were no significant differences observed in $\mathrm{pD}_{2}$ or $\mathrm{E}_{\max }$ values for warifteine-induced relaxations in endothelium-intact and -denuded rings, all subseqnent experiments were performed in endothelium-denuded rings. The time required for maximal 


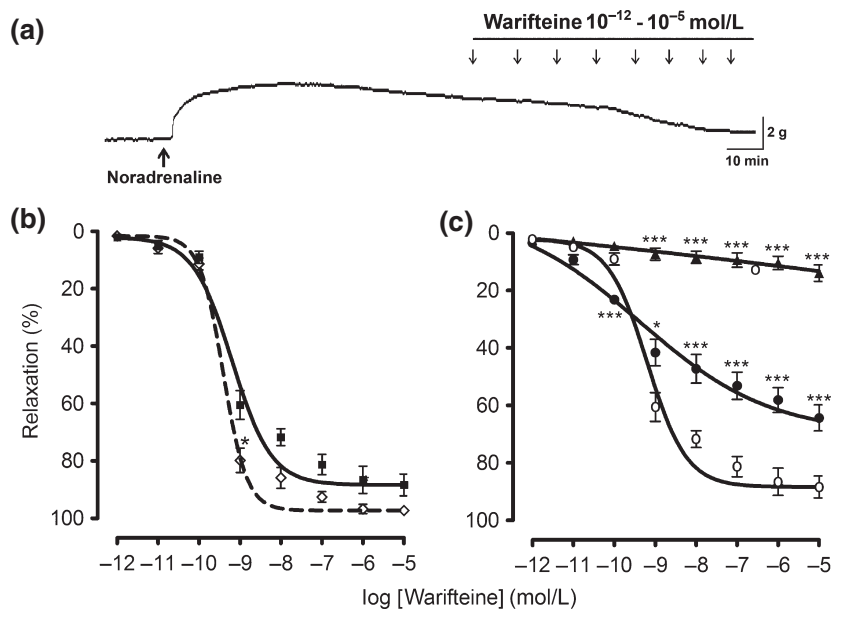

Fig. 2 Vasorelaxant effects of warifteine in rat aortic rings. (a) Representative trace showing the vasorelaxant effects of warifteine in endothelium-denuded aortic rings precontracted with noradrenaline $(10 \mu \mathrm{mol} / \mathrm{L})$. (b) Concentration-response curves to warifteine $(1 \mathrm{pmol} / \mathrm{L}-10 \mu \mathrm{mol} / \mathrm{L})$ in endothelium-intact $(n=9 ; \diamond)$ and endothelium-denuded $(n=7 ; \mathbf{\square})$ noradrenaline (10-100 $\mu \mathrm{mol} / \mathrm{L})$-precontracted rings. (c) Relaxation responses to warifteine in endothelium-denuded aortic rings precontracted with noradrenaline $(10-100 \mu \mathrm{mol} / \mathrm{L} ; n=7 ; \mathbf{\square})$, prostaglandin $\mathrm{F}_{2 \alpha}(1-10 \mathrm{mmol} / \mathrm{L}$; $n=8 ; \bullet)$ and $\mathrm{KCl}(80 \mathrm{mmol} / \mathrm{L} ; n=6 ; \boldsymbol{\Delta})$. Results are the mean \pm SEM. $* P<0.05, * * P<0.01, \quad * * * P<0.001$ compared with endothelium-intact (b) or noradrenaline-precontracted (c) rings (one-way ANOVA with Bonferroni correction; eight (b) or 16 (c) comparisons).

Table 1 Potency $\left(\mathrm{pD}_{2}\right)$ of and maximum responses $\left(\mathrm{E}_{\max }\right)$ to warifteine in rat aortic rings

\begin{tabular}{|c|c|c|c|}
\hline & $n$ & $\mathrm{pD}_{2}$ & $\mathrm{E}_{\max }(\%)$ \\
\hline Endothelium intact & 5 & $9.40 \pm 0.06$ & $97.3 \pm 1.3$ \\
\hline Endothelium denuded (control) & 5 & $9.20 \pm 0.01$ & $88.4 \pm 3.8$ \\
\hline $\mathrm{PGF}_{2 \alpha}(1-10 \mathrm{mmol} / \mathrm{L})$ & 8 & $9.20 \pm 0.19$ & $64.4 \pm 4.5^{*}$ \\
\hline \multicolumn{4}{|l|}{$\mathrm{KCl}(\mathrm{mmol} / \mathrm{L})$} \\
\hline 80 & 6 & - & $14.0 \pm 2.3 * * *$ \\
\hline 20 & 5 & $6.75 \pm 0.63^{* * *}$ & $41.8 \pm 4.1 * * *$ \\
\hline \multicolumn{4}{|l|}{ Tetraethylammonium $(\mathrm{mmol} / \mathrm{L})$} \\
\hline 1 & 6 & $8.00 \pm 0.35$ & $76.2 \pm 8.9$ \\
\hline 3 & 5 & $6.57 \pm 0.17 * * *$ & $48.8 \pm 5.3^{* * *}$ \\
\hline 5 & 5 & $8.07 \pm 0.30$ & $37.7 \pm 3.7$ \\
\hline Iberiotoxin $(20 \mathrm{nmol} / \mathrm{L})$ & 6 & $6.56 \pm 0.24 * * *$ & $41.2 \pm 5.1$ *** \\
\hline Glibenclamide $(10 \mu \mathrm{mol} / \mathrm{L})$ & 5 & $8.14 \pm 0.12$ & $96.4 \pm 3.2$ \\
\hline 4-Aminopyridine $(1 \mathrm{mmol} / \mathrm{L})$ & 7 & $8.37 \pm 0.19$ & $93.3 \pm 3.2$ \\
\hline $\mathrm{BaCl}_{2}(1 \mathrm{mmol} / \mathrm{L})$ & 5 & $8.85 \pm 0.16$ & $93.9 \pm 4.6$ \\
\hline
\end{tabular}

Data are the mean \pm SEM.

$* P<0.05$. and $* * * P<0.001$ compared with endothelium-denuded control (one-way ANOva followed by Bonferroni's post test; 11 comparisons).

responses to each concentration of warifteine to be reached ranged from 10 to $15 \mathrm{~min}$.

A series of experiments was designed to determine whether warifteine was competing with noradrenaline to induce relaxation via blockade of adrenoceptors. In one set of experiments, blood vessels were precontracted via $\mathrm{PGF}_{2 \alpha}(1-10 \mathrm{mmol} / \mathrm{L})$-mediated stimulation of prostanoid FP receptors. In another set of experiments, arteries were precontracted by high- $\mathrm{K}^{+}(80 \mathrm{mmol} / \mathrm{L})$. As indicated in Fig. 2c and Table 1, the inhibitory effects of warifteine were not limited to noradrenaline-induced contractions because warifteine also induced concentration-dependent relaxation of $\mathrm{PGF}_{2 \alpha}$-precontracted rings $\left(\mathrm{pD}_{2}=9.20 \pm 0.19 ; n=8\right)$, although the $\mathrm{E}_{\max }$ was significantly attenuated $(64.40 \pm 4.50 \%$; $n=8 ; P<0.01$, ANOVA with Bonferroni's multiple comparisons post-test) when compared with that in noradrenaline-precontracted rings. In contrast, the relaxant activity of warifteine was nearly abolished in high- $\mathrm{K}^{+}(80 \mathrm{mmol} / \mathrm{L})$-precontracted aortic rings $\left(\mathrm{E}_{\max }=13.95 \pm 2.87 \% ; n=6 ; P<0.01\right.$, ANovA with Bonferroni's multiple comparisons post-test).

\section{Role of $\mathrm{K}^{+}$channels in warifteine-induced vasorelaxant response}

Based on the observation that the relaxant activity of warifteine was abolished in high- $\mathrm{K}^{+}(80 \mathrm{mmol} / \mathrm{L})$-precontracted aortic rings, subsequent experiments were performed to investigate the role of $\mathrm{K}^{+}$channels in warifteine-mediated relaxation. As indicated in Fig. 3a and Table 1, $30 \mathrm{~min}$ pretreatment with $20 \mathrm{mmol} / \mathrm{L} \mathrm{KCl}$ significantly inhibited the warifteine-induced vasorelaxant response $(P<0.01$, ANOVA with Bonferroni's multiple comparisons post-test). These findings indicate that $\mathrm{K}^{+}$channel activation plays a critical role in the relaxant effects of warifteine in rat aortic rings. The roles of specific $\mathrm{K}^{+}$channels were also evaluated in experiments using selective $\mathrm{K}^{+}$channel blockers, namely TEA ( 3 and $5 \mathrm{mmol} / \mathrm{L}$; a non-specific $\mathrm{K}^{+}$channel blocker ${ }^{18}$ that has been reported to be more selective for large conductance $\mathrm{Ca}^{2+}$-activated $\mathrm{K}^{+}$channels $\left(\mathrm{BK}_{\mathrm{Ca}}\right)$ at a concentration of $\left.1 \mathrm{mmol} / \mathrm{L}^{19}\right)$, iberiotoxin $(20 \mathrm{nmol} / \mathrm{L}$; a selective inhibitor of $\left.\mathrm{BK}_{\mathrm{Ca}}{ }^{20}\right)$, glibenclamide $\left(10 \mu \mathrm{mol} / \mathrm{L}\right.$; an ATP-sensitive $\mathrm{K}^{+}\left(\mathrm{K}_{\mathrm{ATP}}\right)$ channel blocker $\left.{ }^{21}\right)$, 4-aminopyridine $(1 \mathrm{mmol} / \mathrm{L}$; a blocker of delayed rectifier $\mathrm{K}^{+}\left(\mathrm{K}_{\mathrm{v}}\right)$ channels $\left.{ }^{22}\right)$ and $\mathrm{Ba}^{2+}(1 \mathrm{mmol} / \mathrm{L}$; a blocker of inward rectifier $\mathrm{K}^{+}\left(\mathrm{K}_{\mathrm{ir}}\right)$ channels $\left.{ }^{23}\right)$. As indicated in Fig. $3 \mathrm{~b}$ and Table 1, when aortic rings were incubated with 1,3 and $5 \mathrm{mmol} / \mathrm{L}$ TEA, $\mathrm{pD}_{2}$ and $\mathrm{E}_{\max }$ values to warifteine were significantly attenuated (ANOVA with Bonferroni's multiple comparisons post-test) compared with control. In addition, the relaxation induced by warifteine was strongly inhibited when aortic rings were exposed to iberiotoxin (Fig. 3c; Table 1). Glibenclamide had a significant effect on responses to warifteine only at a concentration of $10^{-9} \mathrm{~mol} / \mathrm{L}$ (Fig. 3d; Table 1), whereas $\mathrm{Ba}^{2+}$ and 4-aminopyridine had no significant effect on warifteineinduced relaxation (Fig. 3f; Table 1). These observations indicate that warifteine elicits vasorelaxation by modulating $\mathrm{K}^{+}$channels, mostly $\mathrm{BK}_{\mathrm{Ca}}$ activation.

\section{Warifteine increases $\mathrm{K}^{+}$current in vascular myocytes}

The effects of warifteine on $\mathrm{K}^{+}$currents were examined using whole-cell voltage-clamp techniques in freshly dissociated vascular myocytes isolated from the rat aorta. Cells were depolarized from a holding potential of $-40 \mathrm{mV}$ to test potentials in the range -50 to $70 \mathrm{mV}$ using $10 \mathrm{mV}$ steps. Figure 4a shows representative traces obtained at $70 \mathrm{mV}$ before and after exposure of cells to warifteine $(100 \mathrm{nmol} / \mathrm{L})$. The time required to achieve the maximum effect was approximately $10 \mathrm{~s}$. Figure $4 \mathrm{~b}$ summarizes the current-voltage relationship in the absence and presence of warifteine $(100 \mathrm{nmol} / \mathrm{L})$. Under these recording conditions 


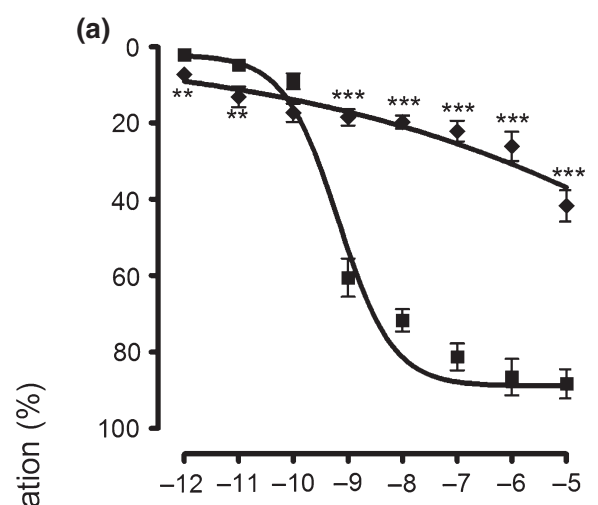

(b)
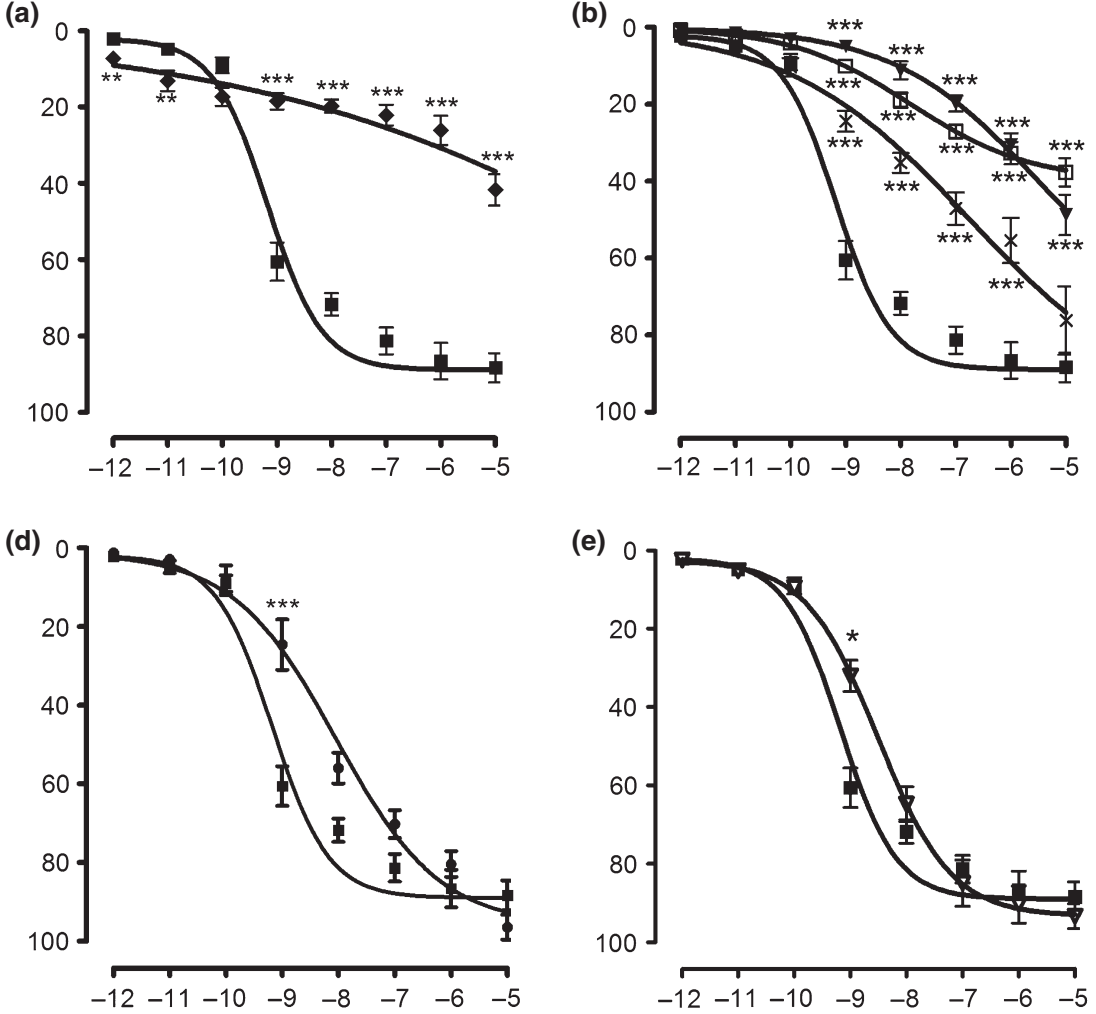

(e)

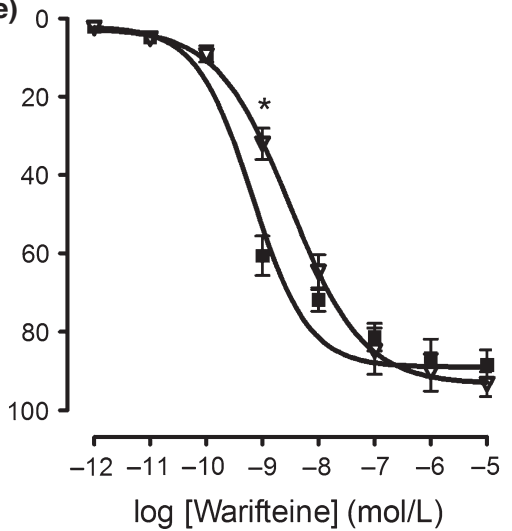

(c)

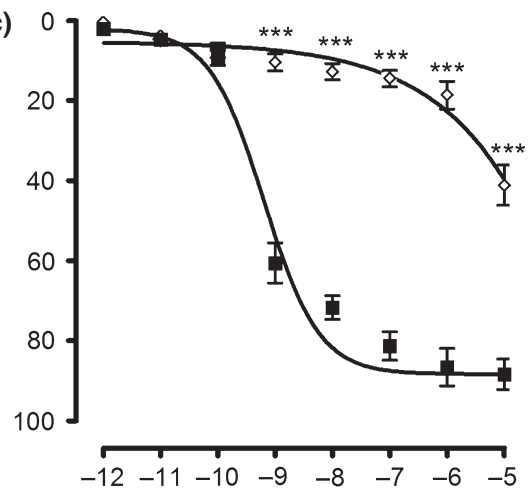

(f)

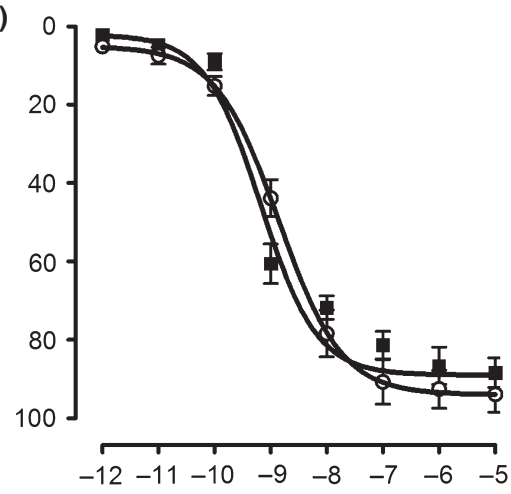

Fig. 3 Effects of various $\mathrm{K}^{+}$channel blockers on warifteine-induced relaxation in noradrenaline-precontracted endothelium-denuded aortic rings. Rings were pretreated with (a) $20 \mathrm{~mol} / \mathrm{L} \mathrm{KCl}$, (b) $1(\times), 3$ ( $\boldsymbol{\nabla}$ ) or $5 \mathrm{mmol} / \mathrm{L}$ ( $\square$ ) tetraethylammonium, (c) $20 \mathrm{nmol} / \mathrm{L}$ iberiotoxin $(\diamond)$, (d) $10 \mu \mathrm{mol} / \mathrm{L}$ glibenclamide $(\diamond)$, (e) $1 \mathrm{mmol} / \mathrm{L}$ 4-aminopyridine $(\nabla)$ or (f) $1 \mathrm{mmol} / \mathrm{L} \mathrm{BaCl}{ }_{2}(\bigcirc)$ for $30 \mathrm{~min}$ prior to construction of warifteine concentration-response curves. $(\square)$, control. Data are the mean \pm SEM $(n=5-7) .{ }^{*} P<0.05,{ }^{* *} P<0.01,{ }^{* * *} P<0.001$ compared with control (one-way ANova with Bonferroni correction; 16 (a,c-f) and 24 (b) comparisons).

(dialysed cells with a pipette solution containing $5 \mathrm{mmol} / \mathrm{L}$ EGTA), the addition of warifteine significantly $(P<0.05$, paired Student's $t$-test) increased $\mathrm{K}^{+}$currents in the range $60-70 \mathrm{mV}$, demonstrating that warifteine is able to interfere with $\mathrm{K}^{+}$channels in single rat vascular myocytes.

\section{Effects of warifteine on $\mathrm{CaCl}_{2}$-induced contractions}

The ability of warifteine to directly influence $\mathrm{Ca}^{2+}$ influx was evaluated by studying its effects on contractile responses to $\mathrm{CaCl}_{2}$ in rat aortic rings that had been stimulated with either noradrenaline $(100 \mu \mathrm{mol} / \mathrm{L})$ or high $\mathrm{K}^{+}(60 \mathrm{mmol} / \mathrm{L})$ in the absence of extracellular $\mathrm{Ca}^{2+}$. Figure $5 \mathrm{a}$ shows the effects of warifteine $(10 \mu \mathrm{mol} / \mathrm{L})$ on $\mathrm{CaCl}_{2}$-induced contractions in noradrenaline $(100 \mu \mathrm{mol} / \mathrm{L})$-stimulated rat aortic rings depleted of intracellular $\mathrm{Ca}^{2+}$. In these preparations, the addition of a single concentration of $\mathrm{CaCl}_{2}(2 \mathrm{mmol} / \mathrm{L})$ resulted in contraction of the aortic rings. Pre-incubation with warifteine $(10 \mu \mathrm{mol} / \mathrm{L})$ for $15 \mathrm{~min}$ had no significant effect on the responses to $\mathrm{CaCl}_{2}$. When vessels were stimulated with high- $\mathrm{K}^{+}(60 \mathrm{mmol} / \mathrm{L})$ under nominally $\mathrm{Ca}^{2+}$-free conditions, the cumulative addition of $\mathrm{CaCl}_{2}$ (from $1 \mu \mathrm{mol} / \mathrm{L}$ to $30 \mathrm{mmol} / \mathrm{L}$ ) induced concentration-dependent contractions. Warifteine $(10 \mu \mathrm{mol} / \mathrm{L})$ had no effect on concentration-response curves to $\mathrm{CaCl}_{2}$ (Fig. 5b), indicating that direct inhibition of $\mathrm{Ca}^{2+}$ influx is not likely to be involved in warifteine-induced relaxation of rat aortic rings.

\section{DISCUSSION}

The present study demonstrates possible mechanisms by which warifteine causes vasorelaxation of the rat aorta. Our findings demonstrate that warifteine elicits a potent relaxation of the rat aorta and this response is likely mediated via the increased open probability of $\mathrm{K}^{+}$channels in the vascular smooth muscle.

The pharmacological actions of vasodilator compounds are due mainly to either a direct effect on vascular smooth muscle or an indirect effect mediated by the release of a relaxing factor(s) from endothelial cells. ${ }^{24}$ The present study has shown that the vasodilator response to warifteine is not altered by mechanical removal of the endothelium, indicating that the actions of warifteine are due to a direct effect on vascular smooth muscle.

Warifteine-mediated vasodilatation was not limited to contractile responses evoked by a single vasoconstrictor. In the present study, warifteine effectively relaxed arteries that had been contracted by two different receptor-dependent constrictors, namely noradrenaline (an adrenoceptor agonist) and $\mathrm{PGF}_{2 \alpha}$ (a prostanoid FP receptor agonist), suggesting that warifteine may interfere with multiple receptor-mediated vasoconstrictor mechanisms. However, warifteine had a smaller effect on rings contracted with $\mathrm{PGF}_{2 \alpha}$. In addition, warifteine had little effect on contractions induced by high $\mathrm{K}^{+}(80 \mathrm{mmol} / \mathrm{L})$. It is well-known that potassium-mediated smooth muscle contractions are initiated by membrane depolarization, resulting in an increase in $\mathrm{Ca}^{2+}$ influx via 
(a)
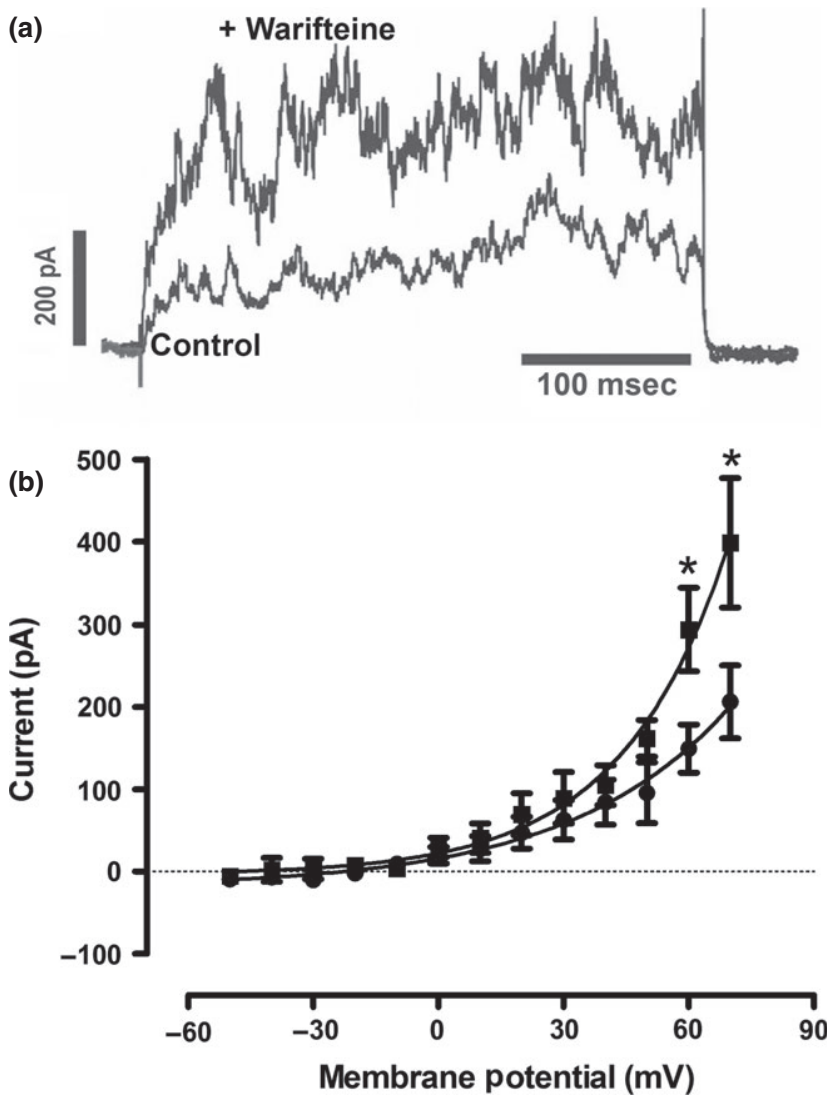

Fig. 4 Warifteine increases $\mathrm{K}^{+}$currents in vascular myocytes isolated from rat aorta. (a) Original $\mathrm{K}^{+}$current traces before (control) and after the application of $100 \mathrm{nmol} / \mathrm{L}$ warifteine. (b) Current-voltage relationships showing the effects of warifteine $(100 \mathrm{nmol} / \mathrm{L})$ on macroscopic $\mathrm{K}^{+}$current in rat aortic smooth muscle cells. Data are the mean $\pm \operatorname{SEM}(n=4)$. $* P<0.05$ compared with control (repeated-measures ANOva with Bonferroni correction).

voltage-gated (L- and T-type) $\mathrm{Ca}^{2+}$ channels. ${ }^{25,26}$ The membrane depolarization results from increasing the extracellular $\mathrm{K}^{+}$concentration, which reduces the electrochemical gradient for $\mathrm{K}^{+}$ efflux. The lack of effect of warifteine under these conditions strongly suggests that $\mathrm{K}^{+}$channel activation plays a predominant role in warifteine-mediated relaxation. This was further supported by the observation that the reduced $\mathrm{K}^{+}$efflux gradient (Krebs' solution containing $20 \mathrm{mmol} / \mathrm{L} \mathrm{KCl}$ ) largely inhibited the vasorelaxant effect of warifteine against noradrenaline-induced contractions in rat aortic rings.

Several types of $\mathrm{K}^{+}$channels have been identified in vascular smooth muscle. The most abundant include $\mathrm{BK}_{\mathrm{Ca}}$ and $\mathrm{K}_{\mathrm{v}}$, although $\mathrm{K}_{\mathrm{ATP}}$ and $\mathrm{K}_{\mathrm{ir}}$ channels are also present. ${ }^{27,28}$ Activation of these channels increases $\mathrm{K}^{+}$efflux, producing hyperpolarization of vascular smooth muscle. Therefore, the activity of these potassium channels plays an essential role in regulating membrane potential and vascular tone. ${ }^{29}$ Moreover, changes in the expression and function of arterial $\mathrm{K}^{+}$channels have been observed in diseases such as hypertension, ${ }^{30}$ and $\mathrm{K}^{+}$channel activators have proven to be clinically effective for the treatment of a variety of cardiovascular disorders. ${ }^{31}$

In the present study, we pretreated aortic rings with several $\mathrm{K}^{+}$ channel blockers to further test the hypothesis that warifteine (a)

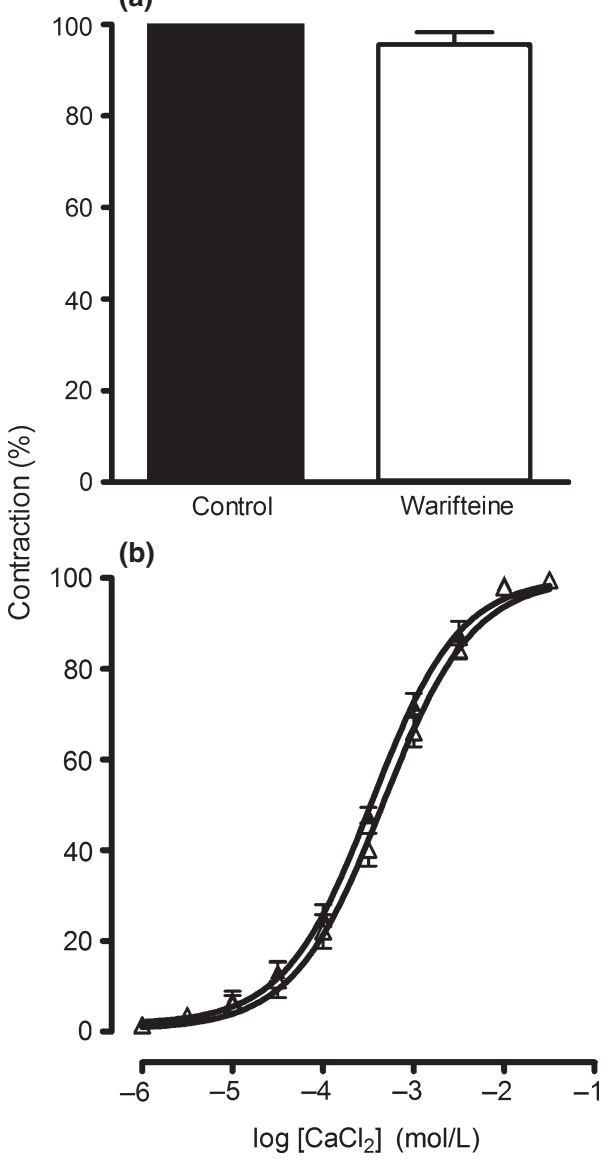

Fig. 5 Effects of warifteine on contractile responses to $\mathrm{CaCl}_{2}$. (a) $\mathrm{CaCl}_{2}$-induced contractions of noradrenaline $(100 \mu \mathrm{mol} / \mathrm{L})$-precontracted rat aortic rings in the absence (control) and presence of $10 \mu \mathrm{mol} / \mathrm{L}$ warifteine. (b) Concentration-response curves to $\mathrm{CaCl}_{2}$ in $\mathrm{KCl}$-precontracted aortic rings in the absence (control; $\boldsymbol{\Delta}$ ) and presence of $10 \mu \mathrm{mol} / \mathrm{L}$ warifteine $(\triangle)$. Data are the mean $\pm \operatorname{SEM}(n=5)$. Statistical analyses were performed using paired Student's two-tailed $t$-tests.

induces vasorelaxation by activating $\mathrm{K}^{+}$channels. We found that the vasorelaxant effects of warifteine were modified by inhibition of $\mathrm{BK}_{\mathrm{Ca}}$ and $\mathrm{K}_{\mathrm{ATP}}$ channels. Furthermore, inhibition of $\mathrm{K}_{\mathrm{ir}}$ and $\mathrm{K}_{\mathrm{v}}$ channels had no effect on the concentration-response curve to warifteine. These findings indicate that the concentration-dependent relaxation elicited by warifteine involves activation of $\mathrm{K}^{+}$ channels in the rat aorta.

The patch-clamp technique was used to gain further insight into the vascular effects of warifteine and to confirm the stimulatory effect of warifteine on $\mathrm{K}^{+}$channels. Warifteine, at concentrations that relaxed the rat aorta, increased $\mathrm{K}^{+}$currents recorded in single smooth muscle cells isolated from the same preparations, reinforcing our hypothesis that activation of $\mathrm{K}^{+}$ current contributes to warifteine-induced relaxation. However, additional studies are needed to completely clarify the molecular events underlying $\mathrm{K}^{+}$current activation. Nevertheless, it is possible that $\mathrm{BK}_{\mathrm{Ca}}$ channels are preferentially activated by warifteine due to the significant increase in $\mathrm{K}^{+}$current only between 60 and $70 \mathrm{mV}$ in cells dialysed with a pipette solution containing $5 \mathrm{mmol} / \mathrm{L}$ EGTA. The $\mathrm{BK}_{\mathrm{Ca}}$ channels are classically opened by a combination of membrane depolarization and elevated 
cytosolic $\mathrm{Ca}^{2+}$ concentrations. ${ }^{32}$ Under conditions that do not alter the concentration of intracellular $\mathrm{Ca}^{2+}$, these channels can be activated through increasing depolarization steps, as demonstrated by Mistry and Garland. ${ }^{33}$ Previous studies have demonstrated that when physiological levels of intracellular $\mathrm{Ca}^{2+}$ are maintained, the maximum current through $\mathrm{BK}_{\mathrm{Ca}}$ channels occurs between 60 and $80 \mathrm{mV}$. However, the increase in $\mathrm{Ca}^{2+}$ concentration during inside-out studies clearly demonstrates that when varying the $\mathrm{Ca}^{2+}$ concentration, the maximum membrane potential current reached is between 0 and $10 \mathrm{mV} .{ }^{33}$ Under conditions of low cytosolic $\mathrm{Ca}^{2+}$ concentrations, as used in the present study, we speculate that warifteine alters $\mathrm{K}^{+}$channel conductance, potentially through $\mathrm{BK}_{\mathrm{Ca}}$ channel activity and principally in the voltage range at which warifteine demonstrated stimulatory actions on $\mathrm{K}^{+}$currents.

We also investigated whether warifteine-induced vasorelaxation was related to the direct inhibition of $\mathrm{Ca}^{2+}$ influx through VDCC channels, independent of $\mathrm{K}^{+}$channel opening. In high$\mathrm{K}^{+}(60 \mathrm{mmol} / \mathrm{L})$, nominally $\mathrm{Ca}^{2+}$-free Krebs' solution, contractions were evoked by the cumulative addition of $\mathrm{CaCl}_{2}$. It is important to note that this medium has a high $\mathrm{K}^{+}$concentration, which is known to reduce the electrochemical gradient for $\mathrm{K}^{+}$ efflux and to negatively affect the vasorelaxation effect related to $\mathrm{K}^{+}$channel activation. Thus, it was possible to assess the direct effect of warifteine on $\mathrm{Ca}^{2+}$ influx, independent of hyperpolarization. Our results indicate that warifteine does not produce a significant change in $\mathrm{Ca}^{2+}$ influx under these conditions. Together, our results support the hypothesis that the actions of warifteine include increasing the open probability of $\mathrm{K}^{+}$channels but that warifteine is not an active $\mathrm{Ca}^{2+}$ channel blocker in the rat aorta.

Warifteine-mediated vasorelaxation was initially demonstrated in rabbit aorta. ${ }^{12}$ However, the mechanisms observed in the present study are distinct from those described earlier in rabbit aortic preparations, in which inhibition of voltage-gated $\mathrm{Ca}^{2+}$ channels appeared to be the principal underlying mechanism. These differences may be explained by the unique responses observed in different animal species. It is evident that the pharmacological characteristics are not uniform between different vascular beds or even between the same vessels from different species. ${ }^{34}$ There are substantial differences in the degree of innervations, ${ }^{35}$ the use of intracellular and extracellular calcium for contractions ${ }^{36,37}$ and in receptor expression profiles. ${ }^{38-40}$

In conclusion, the present study provides experimental evidence for a key mechanism by which warifteine relaxes the rat aorta, which increases the understanding as to how warifteine and other related bisbenzylisoquinoline alkaloids mediate vasorelaxation in vitro. The findings of the present study strongly suggest that the vasorelaxant effects of warifteine may be due to changes in the open probability of $\mathrm{K}^{+}$channels.

\section{ACKNOWLEDGEMENTS}

The authors sincerely thank José Crispim Duarte and Raimundo Nonato da Silva (Laboratory of Pharmaceutical Technology, Federal University of Paraíba, João Pessoa, Brazil) for technical assistance. The authors also thank Conselho Nacional de Desenvolvimento Científico e Tecnológico (CNPq), Coordenação de Aperfeiçoamento de Pessoal de Nível Superior (CAPES) and
Fundação de Amparo à Pesquisa do Estado de Minas Gerais (FAPEMIG) for financial support. The authors have no conflicts of interest to declare.

\section{REFERENCES}

1. Elliott WJ. Systemic hypertension. Curr. Probl. Cardiol. 2007; 32: 201-59.

2. Zeng Y, Gu B, Ji X, Ding X, Song C, Wu F. Sinomenine, an antirheumatic alkaloid, ameliorates clinical signs of disease in the lewis rat model of acute experimental autoimmune encephalolmyelitis. Biol. Pharm. Bull. 2007; 30: 1438-44.

3. Noor H, Ashcroft SJH. Pharmacological characterization of the antihyperglycaemic properties of Tinospora crispa extract. J. Ethnopharmacol. 1998; 62: 7-13.

4. Moody JO, Robert VA, Connolly JD, Houghton PJ. Anti-inflammatory activities of the methanol extracts and an isolated furanoditerpene constituent of Sphenocentrum jollyanum Pierre (Menispermaceae). J. Ethnopharmacol. 2006; 104: 87-91.

5. Amresh G, Reddy GD, Rao CV, Singh PN. Evaluation of antiinflammatory activity of Cissampelos pareira root in rats. J. Ethnopharmacol. 2007; 110: 526-31.

6. Kondo Y, Imai Y, Kubota Y, Hojo H, Nozoe S. Inhibitory effect of bisbenzylisoquinoline alkaloids on the quick death of mice treated with BCG/LPS. Chem. Pharm. Bull. 1990; 38: 2887-9.

7. Kondo Y, Takano F, Hojo H. Suppression of lipopolysaccharideinduced fulminant hepatitis and tumor necrosis factor production by bisbenzylisoquinoline alkaloids in bacillus Calmette-Guerin-treated mice. Biochem. Pharmacol. 1993; 46: 1861-3.

8. Qian JQ, Thoolen MJ, Van Meel JC, Timmermans PB, Van Zwieten PA. Hypotensive activity of tetrandrine in rats. Investigation into its mode of action. Pharmacology 1983; 26: 187-97.

9. Kwan CY, Achike F. Tetrandrine and related bis-benzylisoquinoline alkaloids from medicinal herbs. Cardiovascular effects and mechanisms of action. Acta Pharmacol. Sin. 2002; 23: 1057-68.

10. Qian JQ. Cardiovascular pharmacological effects of bisbenzylisoquinoline alkaloid derivatives. Acta Pharmacol. Sin. 2002; 23: 1086 -92 .

11. Bezerra-Santos CR, Vieira-de-Abreu A, Barbosa-Filho JM, Bandeira-Melo C, Piuvezam MR, Bozza PT. Anti-allergic properties of Cissampelos sympodialis and its isolated alkaloid warifteine. Int. Immunopharmacol. 2006; 6: 1152-60.

12. Freitas MR, Cortês SF, Thomas G, Barbosa-Filho JM. Modification of $\mathrm{Ca}^{2+}$ metabolism in the rabbit aorta as a mechanism of spasmolytic action of warifteine, a bisbenzylisoquinoline alkaloid isolated from the leaves of Cissampelos sympodialis Eichl. (Menispermaceae). J. Pharm. Pharmacol. 1996; 48: 332-6.

13. Piuvezam MR, Peçanha LM, Alexander J, Thomas G. Cissampelos sympodialis Eichl. leaf extract increases the production of IL-10 by concanavalin-A-treated BALB/c spleen cells. J. Ethnopharmacol. 1999; 67: 93-101.

14. Almeida RN, Navarro DS, De Assis TS, Medeiros IA, Thomas G. Antidepressant effect of an ethanolic extract of the leaves of Cissampelos sympodialis in rats and mice. J. Ethnopharmacol. 1998; 63: 247-52.

15. Cai B, Gong D, Pan $\mathrm{Z}$ et al. Large-conductance $\mathrm{Ca}^{2+}$-activated $\mathrm{K}^{+}$ currents blocked and impaired by homocysteine in human and rat mesenteric artery smooth muscle cells. Life Sci. 2007; 80: 2060-6.

16. Hamill OP, Marty A, Neher E, Sakmann B, Sigworth FJ. Improved patch-clamp technique for high resolution current recording from cells and cell-free membrane patches. Pflugers Arch. 1981; 391: 85100 .

17. Bezanilla F, Armstrong CM. Inactivation of the sodium channel. I. Sodium current experiments. J. Gen. Physiol. 1977; 70: 549-66.

18. Wang SP, Zang WJ, Kong SS et al. Vasorelaxant effect of isopropyl-3-(3,4-dihydroxyphenyl)-2-hydroxypropanoate, a novel 
metabolite from Salvia miltiorrhiza, on isolated rat mesenteric artery. Eur. J. Pharmacol. 2008; 579: 283-8.

19. Langton PD, Nelson MT, Huang Y, Standen NB. Block of calciumactivated potassium channels in mammalian arterial myocytes by tetraethylammonium ions. Am. J. Physiol. Heart Circ. Physiol. 1991; 260: H927-34.

20. Satake N, Shibata M, Shibata S. The inhibitory effects of iberiotoxin and 4-aminopyridine on the relaxation induced by $\beta_{1^{-}}$and $\beta_{2}$-adrenoceptor activation in rat aortic rings. Br. J. Pharmacol. 1996; 119: 505-10.

21. Randall MD, Kendall DA. Involvement of a cannabinoid in endothelium-derived hyperpolarizing factor-mediated coronary vasorelaxation. Eur. J. Pharmacol. 1997; 335: 205-9.

22. Honda $\mathrm{H}$, Unemoto $\mathrm{T}$, Kogo $\mathrm{H}$. Different mechanisms for testosterone-induced relaxation of aorta between normotensive and spontaneously hypertensive rats. Hypertension 1999; 34: 1232-6.

23. Niu LG, Zhang MS, Liu Y et al. Vasorelaxant effect of taurine is diminished by tetraethylammonium in rat isolated arteries. Eur. J. Pharmacol. 2008; 580: 169-74.

24. Gurney AM. Mechanisms of drug-induced vasodilation. J. Pharm. Pharmacol. 1994; 46: 242-51.

25. Thorneloe KS, Nelson MT. Ion channels in smooth muscle. Regulators of intracellular calcium and contractility. Can. J. Physiol. Pharmacol. 2005; 83: 215-42.

26. Cribbs LL. T-Type $\mathrm{Ca}^{2+}$ channels in vascular smooth muscle: Multiple functions. Cell Calcium 2006; 40: 221-30.

27. Brayden JE. Potassium channels in vascular smooth muscle. Clin. Exp. Pharmacol. Physiol. 1996; 23: 1069-76.

28. Ko EA, Han J, Jung ID, Park WS. Physiological roles of $\mathrm{K}^{+}$channels in vascular smooth muscle cells. J. Smooth Muscle Res. 2008; 44: $65-81$.

29. Nelson MT, Quayle JM. Physiological roles and properties of potassium channels in arterial smooth muscle. Am. J. Physiol. 1995; 268: C799-822.

30. Cox RH. Changes in the expression and function of arterial potassium channels during hypertension. Vasc. Pharmacol. 2002; 38: $13-23$.
31. Richer C, Pratz J, Mulder P, Mondot S, Giudicelli JF, Cavero I. Cardiovascular and biological effects of $\mathrm{K}^{+}$channel openers, a class of drugs with vasorelaxant and cardioproctive properties. Life Sci. 1990; 47: 1693-705.

32. Ghatta S, Nimmagadda D, Xu X, O'Rourke ST. Large-conductance, calcium-activated potassium channels: Structural and functional implications. Pharmacol. Ther. 2006; 110: 103-16.

33. Mistry DK, Garland CJ. Characteristics of single, large-conductance calcium-dependent potassium channels $\left(\mathrm{BK}_{\mathrm{Ca}}\right)$ from smooth muscle cells isolated from the rabbit mesenteric artery. J. Membr. Biol. 1998; 164: 125-38.

34. Blaylock NA, Wilson VG. Pharmacological characterization of noradrenaline-induced contractions of the porcine isolated palmar lateral vein and palmar common digital artery. Br. J. Pharmacol. 1995; 114: 694-702.

35. Patil PN, Fudge K, Jacobowitz D. Steric aspects of adrenergic drugs. 18. -Adrenergic receptors of mammalian aorta. Eur. J. Pharmacol. 1972; 19: 79-87.

36. Beckeringh JJ, Thoolen MJ, De Jonge A, Wilffert B, Timmermans $\mathrm{PB}$, Van Zwieten PA. The contractions induced in rat and guineapig aortic strips by the $\alpha_{2}$-adrenoceptor selective agonists B-HT 920 and UK 14,304 are mediated by $\alpha_{1}$-adrenoceptors. Eur. J. Pharmacol. 1984; 104: 197-203.

37. Jenkin RA, Baldi MA, Iwanov V, Moulds RF. Differences between rat and guinea pig aorta in postreceptor mechanisms of $\alpha_{1}$-adrenoceptors. J. Cardiovasc. Pharmacol. 1991; 18: 566-73.

38. Ruffolo RR Jr, Waddell JE. Receptor interactions of imidazolines: A-adrenoceptors of rat and rabbit aortae differentiated by relative potencies, affinities and efficacies of imidazoline agonists. $\mathrm{Br}$. J. Pharmacol. 1982; 77: 169-76.

39. Ruffolo RR Jr, Waddell JE, Yaden EL. Heterogeneity of postsyn aptic $\alpha$-adrenergic receptors in mammalian aortas. J. Pharmacol. Exp. Ther. 1982; 221: 309-14.

40. Nielsen H, Pilegaard HK, Hasenkam JM, Mortensen FV, Mulvany MJ. Heterogeneity of postjunctional $\alpha$-adrenoceptors in isolated mesenteric resistance arteries from rats, rabbits, pigs, and humans. J. Cardiovasc. Pharmacol. 1991; 18: 4-10. 